\title{
Legal Protection for People with Disabilities in the Perspective of Human Rights in Indonesia
}

\author{
Faissal Malik ${ }^{1, *}$, Syawal Abduladjid ${ }^{1}$, Dewa Gede Sudika Mangku², Ni Putu Rai Yuliartini ${ }^{2}$, \\ I Gusti Made Arya Suta Wirawan ${ }^{2}$ and Putu Ronny Angga Mahendra ${ }^{3}$
}

\author{
${ }^{1}$ Faculty of Law, Universitas Khairun Ternate, Jln. Jusuf Abdurrachman Kel. Gambesi Kec. Kota Ternate \\ Utara. Provinsi Maluku Utara Indonesia \\ ${ }^{2}$ Faculty of Law and Social Sciences, Universitas Pendidikan Ganesha, Jalan Udayana No. 11 Singaraja Bali \\ Indonesia \\ ${ }^{3}$ Faculty of Teacher Training and Education, Universitas Dwijendra, Jalan Kamboja No. 17 Denpasar Bali \\ Indonesia
}

\begin{abstract}
The purpose of this research is to find out how the principles of legal protection for persons with disabilities and how the implementation of legal protection for persons with disabilities. Indonesia has strong legal principles in making Indonesia a constitutional state with the existence of regulations on guarantees for the protection and empowerment of persons with disabilities which are reflected in; Pancasila as the state philosophy, the Preamble of the 1945 Constitution, Law, TAP MPR, Conventions and International Declarations on human rights. Likewise, legal recognition of persons with disabilities can be seen from the regulations, both Indonesian state regulations, and regulations, or international organizations that provide legal guarantees for the rights of persons with disabilities.
\end{abstract}

Keyword: Disability, human rights, legal protection, human rights, Indonesia.

\section{INTRODUCTION}

The obligation to respect human rights is reflected in the Preamble to the 1945 Constitution which animates all articles, especially those related to the equal status of citizens in law and government, the right to work and a decent living is reflected in the 1945 Constitution Article 27 paragraph (2) "Every citizen. The state has the right to work and a decent living for humanity "freedom of association and assembly, the right to express thoughts in oral and written form, freedom to embrace a religion and worship by its religion and belief, and the right to obtain education and teaching. The Indonesian government plays an important role in the progress of a country that provides guarantees for a safe and decent life for every society, the right to recognition, guarantees, protection, and certainty of just law and equal treatment before the law.

As Indonesian citizens, persons with disabilities also have the same position, rights, and obligations as other citizens and the government had an obligation to fulfill the rights of persons with disabilities, this is reflected in the existing laws and regulations. Where it explains that every person with disabilities has the same rights as other citizens, there is no discrimination and

*Address correspondence to this author at the Faculty of Law, Universitas Khairun Ternate, Jln. Jusuf Abdurrachman Kel. Gambesi Kec. Kota Ternate Utara. Provinsi Maluku Utara Indonesia; Tel: +62 8213440 7360;

E-mail: faissalmalik10@gmail.com distinction, because human rights do not depend on differences in ethnicity, religion, and even physical disabilities, but ,persons with disabilities still get the treatment they don't deserve, even if they don't. rarely do they encounter discrimination.

The goal of the Indonesian state is the welfare of the people, which means that the state, government, or any organization must protect the human rights of every human being without exception, this means that human rights are the benchmarks and goals in the administration of social life. These rights are inherent in human beings from birth that cannot be contested and are permanent and human rights are rights that are owned by every human being, even since a human being is in the womb he already has his basic rights.

In the amendment to the 1945 Constitution of the Republic of Indonesia the fourth amendment, Chapter $X A$ regulates Human Rights, the addition of the Human Rights formula and guarantees of respect, protection, implementation, and advancement in the 1945 Constitution not solely because of the desire to accommodate developments a view of human rights that is increasingly considered to be important as a global issue, but because it is one of the requirements of a rule of law.

With the human rights formula in the 1945 Constitution, constitutionally the human rights of every citizen and population of Indonesia have been 
guaranteed. In this connection, the Indonesian people have the view that human rights must pay attention to the characteristics of Indonesia and a human right must also be balanced with obligations so that it is hoped that mutual respect and respect for the human rights of each party will be created. One of the aspects of the human rights formula included in the 1945 Constitution is human rights related to social welfare. Equal rights and obligations for all citizens in all aspects of life and livelihood are a prerequisite for achieving social welfare for all Indonesian people (Mangku, 2020).

The Republic of Indonesia which is based on Pancasila and the 1945 Constitution of the Republic of Indonesia respects and upholds human dignity. Human rights as basic rights that are naturally inherent in humans are universal and lasting, are also protected, respected, and defended by the Republic of Indonesia, so that the protection and promotion of human rights, including for vulnerable groups, especially persons with disabilities, also need to be improved.

In the historical range, the Indonesian nation officially declared Human Rights first compared to the United Nations (UN) Universal Declaration of Human Rights, because the Preamble to the 1945 Constitution of the Republic of Indonesia was officially promulgated on 18 August 1945 while the Universal Declaration of Rights UN Human Rights in 1948. This is a fact that shows to the world that the Indonesian nation, before the achievement of the UN human rights statement, in fact, raised human rights in the country. Also, the Indonesian nation from the beginning has had a basic principle that has been rooted in the culture of the Indonesian nation.

No one wants himself to be disabled, either congenital or due to other causes that occur in a person's life, therefore the existence of a disabled citizen is a fact that must be accepted, given the same position, rights, and obligations as citizens according to type and degree. disability as regulated in statutory regulations. To obtain this equality for persons with disabilities is only realized if accessibility is available, which is a facility for persons with disabilities to achieve equal opportunities in obtaining an equal position, rights, and obligations, so it is necessary to make efforts to provide accessibility for persons with disabilities. Thus, persons with disabilities can fully integrate to realize the goals of development and welfare of persons with disabilities. Equality of opportunity for persons with disabilities is essentially the joint responsibility of the Government, local governments, communities, families including parents and persons with disabilities themselves. Therefore, all these elements play an active role to make it happen. Persons with disabilities often do not enjoy the same opportunities as other people due to lack of access to basic services, so they need protection.

By proteting persons with disabilities, the constitutional rights of persons with disabilities are guaranteed and protected so that persons with disabilities can be independent and participate optimally according to human dignity and avoid acts of violence and discrimination. Various facts indicate the existence of unfair treatment and discriminatory attitudes that are still often experienced by persons with disabilities when meeting their basic needs. Among them, the refusal of children with disabilities to enter public schools, the absence of information facilities or work selection tools that can be accessed for participants with disabilities, refusal to access employment opportunities, the lack of public service facilities that are accessible to persons with disabilities, the lack of opportunities and government support in participation in sports for persons with disabilities, stigma against the existence of persons with disabilities and so on. The negative disability stigma has interpreted disability as identical to the sick, weak, unable to afford and will only burden those around them. In this research, we will discuss the Legal Protection of Persons With Disabilities in the Human Rights Perspective Indonesia.

\section{RESEARCH AIM}

The purpose of this study is to provide an explanation and find out about the Legal Protection of Persons with Disabilities in Human Rights Perspective Indonesia. Persons with disabilities have the same position, rights, and obligations as non-disabled people. As part of Indonesian citizens, it is appropriate for persons with disabilities to receive special treatment, which is intended as an effort to protect against vulnerability to various acts of discrimination and especially protection from various human rights violations. This special treatment is seen as an effort to maximize respect, promotion, protection, and fulfillment of universal human rights. Persons with disabilities are a diverse group of people, including persons with disabilities who have physical disabilities, mental disabilities, or a combination of physical and mental disabilities. The condition of persons with disabilities may have little impact on the ability to participate in the community, or even have a large impact, requiring the 
support and assistance of others. Besides, persons with disabilities face greater difficulties than nondisabled people due to obstacles in accessing public services, such as access to education, health, and employment services.

\section{LITERATURE REVIEW}

\subsection{Indonesia is a State of Law and Human Rights}

The State of Indonesia is a rule of law as stated in Article 1 paragraph (3) of the 1945 Constitution of the Republic of Indonesia which reads "The State of Indonesia is the State of Law". Furthermore, in the explanation of the 1945 Constitution, it is stated that "the Indonesian State is based on the law (rechtstaat) not based on mere power (machstaat), therefore the state may not carry out its activities based on mere power, but must be based on law. All forms of law in Indonesia must be able to protect the human rights of every person/citizen. Based on this, it can be interpreted that in carrying out all its duties the actions of the government and the people must be based on law, not arbitrary or deviating from existing or applicable laws and regulations. The idea of a rule of law was started by Plato with his concept "that good state administration is based on good (law) regulation which is called nomoi.

Then the idea of a popular rule of law in the 17th century was a result of the political situation in Europe which was dominated by absolutism. In its development, the understanding of the rule of law cannot be separated from popular understanding. Because in the end, laws that regulate and limit state or government power are interpreted as laws made based on people's power and sovereignty. About the rule of law, people's sovereignty is a material element of the rule of law, in addition to the issue of people's welfare. One of the important principles of rule of law is the principle of legality. The principle of legality is closely related to the idea of democracy and the idea of a rule of law.

The idea of democracy demands that every form of law and various decisions get the approval of people's representatives and pay as much attention to the interests of the people as possible. The idea of a rule of law demands that the administration of state and government must be based on law and provide guarantees for the basic rights of the people as stated in the law. The principle of legality means the effort to create an integral duet in harmony between the understanding of the rule of law and the understanding of people's sovereignty based on the principle of minority as the pillars, which are constitutive. The application of the legality principle will support the enforcement of legal certainty and the enforcement of equal treatment.

The rule of law is an idea that appears to oppose the concept of absolutism which has given birth to a power state. For its time, the rule of law could be called revolutionary because it ended the previous authoritarian form of state. In essence, the power of the ruler must be limited so as not to treat the people arbitrarily. The restriction is carried out using the rule of law, namely that all actions of the ruler must not be at will but must be based and rooted in law, according to the provisions of applicable laws and regulations and for that, there must also be a division of state power.

Apart from the concept of universal human rights, its application must take into account the culture and traditions of the local state, economic factors, or the level of community welfare that can be appointed as an important role holder which ultimately determines the quality of upholding human rights in a country. So it can be interpreted that the better the quality of welfare in a country, the higher its ability to advance the protection of human rights. In its development, human rights are divided into three generations of human rights, namely the first generation of civil and political rights, the second generation covering economic, social, and cultural rights, and the third generation covering rights in development.

Between the three generations cannot be separated from each other, even though the three generations include different rights, but they are still within the unity of human rights that cannot be separated and have interconnectedness between these generations. There is a view that the fulfillment of civil and political rights cannot run well without the fulfillment of economic, social, and cultural rights, as well as the right to development. Economic, social, and cultural rights are an essential part of international human rights law as stated in the international bill of human rights.

The position of economic, social, and cultural rights is very important in terms of being an international human right, it becomes a reference for joint achievement in economic, social, and cultural advancement. Thus, the right to economic, social, and cultural affairs cannot be placed under civil and political rights or other rights. Because of the importance of 
economic, social, and cultural rights, the international community has also made a convention regulating these rights, namely the International Covenant on Economic, Social and Cultural Rights which is accompanied by a convention regulating civil and political rights, namely the International Covenant on Civil and Political Rights on 1966.

\subsection{Rule of Law Theory}

The term rechtsstaat which is translated as rule of law according to Philipus M. Hadjon (1996) has become popular in Europe since the 19th century, although there has been a long history of thinking about it. The idea of a rule of law was put forward for the first time by Plato and then Aristotle emphasized this thought (Huda, 2005). According to Aristotle, it is not humans who rule in a country, but a fair mind and decency that determines the good or bad of a law. According to Aristotle, a good country is a country ruled by a constitution and has the rule of law. He stated (George Sabine, 1995): "Constitutional rule in a state is closely connected, also with the requestion whether is better to be ruled by the best men or the best law, since a government in accordance with the law, accordingly the supremacy of law is accepted by Aristoteles as a mark of good state and not merely as an unfortunate necessity."

Aristotle also put forward three elements of constitutional government. First, the government is implemented for the public interest. Second, governance is carried out according to laws based on general provisions, not laws made arbitrarily that override conventions and the constitution. Third, a constitutional government that is implemented based on the will of the people. Aristotle's thought is recognized as the ideals of the rule of law known to this day. These three elements are almost found and practiced by all countries that identify themselves as a rule of law.

The characteristics of rechtsstaat show that the central idea of rechtsstaat is the recognition and protection of human rights based on the principles of freedom and equality. The existence of the Basic Law theoretically provides constitutional guarantees for such freedom and equality. The distribution of power is intended to prevent the accumulation of power in one hand. The excessive power possessed by a ruler tends to act to curb the freedoms and equality that characterize the rule of law.
In the amendments to the 1945 Constitution, in particular the provisions of Article 1 paragraph (3), it is explicitly stated that Indonesia is a state based on law. Jimly Asshiddiqie compared the meaning of rechtsstaat with rule of law with the important principles of a rule of law which according to The International Commission of Jurist, namely the state must obey the law, the government respects individual rights, as well as free and impartial judiciary (Agus Budi Susilo, 2016 ). By comparing some of these concepts, the principle of a rule of law that is appropriate for the present era has at least twelve characteristics, namely: (1) the supremacy of law; (2) equality in law (equality before the law); (3) the principle of legality (due process of law); (4) limitation of power; (5) independent executive organs; (6) free and impartial trial; (7) there is an administrative court; (8) there is a state administrative court; (9) democratic; (10) serves as a means of realizing the goal of a state (welfare state); (11) transparency; and (12) social control (Siti Nurdjanah, 2017).

Burkens explains the simple meaning of rechsstaat as quoted by A. Hamid S. Attamimi (1992), namely a state that places law as the basis of state power and the exercise of this power in all its forms is carried out under the rule of law. In rechsstaat, according to him, the bond between the state and the law does not take place in a loose or accidental relationship but is an essential one. From this view, it means that the power of government in a country comes from the law and vice versa to implement the law in the administration of a country must be based on power. This is what the Burkens' essential bond may mean. So the two of them cannot be separated from each other because law and power are two simple elements.

\subsection{Overview of Persons with Disabilities in Indonesia}

The Republic of Indonesia which is based on Pancasila and the 1945 Constitution of the Republic of Indonesia respects and upholds human dignity. Human rights as basic rights that are inherently universal, need to be protected, respected and maintained so that protection and human rights for vulnerable groups, especially Persons with Disabilities. Respect, protection, and fulfillment of the rights of persons with disabilities are the obligations of the state. This is also confirmed in the law on human rights so that society has the responsibility to respect the rights of Persons with Disabilities. During this time, Persons with 
Disabilities have experienced a lot of discrimination which results in the unfulfilled implementation of the rights of persons with disabilities.

So far, the regulation regarding persons with disabilities is regulated in Law Number 4 of 1997 concerning Persons with Disabilities, but this regulation does not have a human rights perspective. The content material in Law No.4 of 1997 concerning persons with disabilities is more charity based and the fulfillment of the rights of persons with disabilities is still considered a social problem whose fulfillment policies are only social security, social rehabilitation, social assistance, and improvement of social welfare. Persons with disabilities should have equal opportunities in efforts to develop themselves through independence as dignified human beings.

The passing of Law Number 19 the Year 2011 concerning the Ratification of the Convention on the Rights of Persons with November 10, 2011, shows the commitment and seriousness of the Indonesian Government to respect, protect, and fulfill the rights of persons with disabilities which in turn are expected to improve the welfare of persons with disabilities. Thus, persons with disabilities have the right to be free from torture or cruel, inhuman, degrading treatment, free from exploitation, violence, and abuse, and the right to receive respect for their mental and physical integrity based on equality with others, including in it the right to get social protection and services in the context of independence, as well as in an emergency. Therefore, the Government is obliged to realize the rights contained in the convention, through adjustments to laws and regulations, including ensuring the fulfillment of the rights of persons with disabilities in all aspects of life such as education, health, work, politics and governance, culture and tourism, and the use of technology. information, and communication.

The adoption of the term disability has implications for the orientation of the Indonesian Government's policies, which include:

a) Participating as a country that signed The Convention on the Rights of People with Disabilities in 2004 and ratified it in Law Number 19 of 2009 concerning the Ratification of the Convention on the Rights of Persons with Disabilities;

b) Promote public participation in advancing the rights of persons with disabilities by removing barriers, both physical and social, to public sources such as education and health facilities. Physical barriers that are starting to be removed can be observed with the start of the number of public buildings that have inclined planes and lifts in braille. However, it must continue to be improved because public transportation access is still not in favor of people with disabilities;

c) The involvement of persons with disabilities organizations in the formulation of public policies. This is in line with the principle of "nothing us, without us" as part of the personcentered approach to understanding the needs, problems, hopes, visions, aspirations, and potentials from the perspective of people with disabilities themselves;

d) The elimination of segregation (separation) with inclusion, namely including or inviting people with disabilities as part of the society itself whose needs must be taken into account and their needs are considered.

The scope of regulation in this law covers the fulfillment of equal opportunities for persons with disabilities in all aspects of state and community administration, respect, protection, and fulfillment of the rights of persons with disabilities, including the provision of accessibility and adequate accommodation. The implementation and fulfillment of the rights of persons with disabilities are aimed at realizing a higher quality, fairer, physically and mentally prosperous, and dignified standard of life for persons with disabilities. Also, the implementation and fulfillment of rights are also aimed at protecting persons with disabilities from neglect and exploitation, harassment, and all discriminatory acts, as well as human rights violations.

\section{RESEARCH METHODS}

Research is the main means of developing science, including technology. The research aims to reveal the truth systematically, methodologically, and consistently. Thus, research was conducted through analysis and construction of existing data (Soerjono, Mamudji, 2006). Research is an effort to explore an object that is unclear, obscure, or even without explanation for it. A logical and systematic study of the principles that guide scientific research (methodology) is intended as a basic principle and not as a method (method or design for conducting research) (Sumardjono, 1989). 
Searching for new things through research to find, develop, and test the truth (Wignjosoebroto, 2013) a knowledge (Muslan, 2009). The search through this research must of course meet scientific principles to find answers to a matter, problem, situation, fact, or phenomenon faced by humans. This truth search requires a scientific method to find the truth based on logical considerations (Sumardjono, 2014).

Legal research based on the notion of a legal system as stated by Lawrence M. Friedman consists of three elements, first, a legal substance which consists of norms, rules, legal principles, doctrine, and statutory regulations., the legal structure is the process of forming and implementing the law, consisting of lawmaking, legal bureaucracy, law enforcement, and judicial institutions, including the program, and third, a legal culture which is a form of public appreciation of the law. about where, when, and how people obey and deviate from the law based on their values. Based on Friedman's view, legal research is a study of legal symptoms that is limited to research on norms, rules, and principles as legal substances, law enforcement through the understanding of legal structures, and legal observations in their interactions in society as a legal culture. Normative legal research is research related to the substance of the law, and empirical research (sociology) is research related to the structure and culture of law (Mukti, Achmad, 2010).

Empirical legal research uses primary data through an approach that emphasizes the aspect of observation, while normative legal research uses secondary data with the nature of research which is generally descriptive or descriptive-explorative, with qualitative analysis, and the approach emphasizes abstraction. Legal research to explain or seek answers to something that exists in society by fulfilling certain scientific principles. Of course, legal research that is carried out must be able to provide benefits, both theoretically and practically. The benefits of research, both theoretically and practically, can only be obtained through a certain procedure or method. Procedures or methods in legal research are ways that are taken scientifically to obtain scientific truth.

According to Bernard Arief Sidharta, that normative legal research (legal dogmatic, rechtsdogmatiek), scientific activities include inventory, explanation, interpretation, and systematization including evaluation of the overall positive law (authoritative text) that applies in society or the state. Supported by concepts (meanings), categories, theories, classifications, and methods specially formed and developed to carry out this activity. All activities are directed at preparing efforts to find juridical solutions to micro and macro legal problems that occur in society (Irianto and Shidarta, 2011).

The author's legal research on Legal Protection for Persons With Disabilities From Human Rights Perspective In Indonesia is a type of normative and prospective legal research. This research can qualify as normative legal research, because it examines the rules or norms contained in the law regarding Indonesian government policies regarding the fulfillment of the rights of persons with disabilities in Indonesia, including related laws and regulations, and which are of relevance. with that. This research can also qualify as prospective legal research because this research is expected to provide conceptual input on local government policies, especially Indonesia in fulfilling the rights of persons with disabilities.

\section{DISCUSSION}

\subsection{Legal Protection of Persons With Disabilities In Human Rights Perspective In Indonesia}

Law Number 39 of 1999 concerning Human Rights provides legal certainty for the protection of human rights for everyone. Persons with disabilities are human beings, so human rights for persons with disabilities must be protected and their needs met. Based on the Law of the Republic of Indonesia Number. 39 of 1999 regarding Human Rights in CHAPTER I, General Provisions Article 1, Human Rights are a set of rights inherent in the essence of human existence as a creature of God Almighty and are His gifts that must be respected, upheld, and protected by state, law, government and everyone for the honor and protection of human dignity. Respect and dignification of human rights is a noble thing. The existence of mutual respect, tolerance among fellow creatures of God Almighty, can always provide a sense of peace for anyone in this world (Mangku, 2020).

Since its emergence until today, human rights have undergone development and changes known as the human rights generation, the first generation includes civil and political rights, the second generation includes social, economic, and cultural rights, finally, the third generation contains several collective rights, such as the right to development/progress (development) the right to peace, the right to a clean environment, the 
right to natural wealth and the right to cultural heritage (Satjipto Raharjo, 2009).

The government, society based on the law are obliged to protect and uphold human rights so that the principles, benefits, and equality inherent in all human beings are carried out properly so that there is no more discrimination. What he wants to explain is that people and nations in the world are diverse, diverse in their physical habitats, cultural traditions, values, cosmology, and their views about humans and the world. "The statement contained in the Preamble to the Universal Declaration of Human Rights which was received and announced by the UN General Assembly on December 10, 1948, through resolution No. 217 (III). One of the sentences state "considering that recognition of the natural dignity and the equal and inalienable rights of all members of the human family is the basis of freedom, justice, and world peace. Considering that human rights need to be protected by legal regulations so that people are not forced to choose the path of rebellion as a last resort to oppose tyranny and colonialism. "

These sentences are guidelines for regulations regarding human rights which are also adapted to the legal needs of society and the development of national law based on Pancasila and the 1945 Constitution which is embodied in the Law of the Republic of Indonesia Number 39 of 1999 concerning Human Rights. The conception of human rights, which initially emphasized vertical relations, was mainly influenced by the history of human rights violations that were mainly committed by the state, both on civil-political rights as well as economic, social, and cultural rights. As a consequence, apart from being the government's duty, the main obligation to protect and promote human rights lies with the government. We can see this from the formulations in the Universal Declaration of Human Rights, the International Covenant on Civil and Political Rights, and the International Covenant on Economic, Social, and Cultural Rights, which are state recognition of human rights as the substance of the three instruments. (Awaliyah, et. al., 2020).

As a consequence, it is the state that is burdened with the obligation to protect and promote human rights. The state's obligation is emphasized in the preamble "Considering" both in the International Covenant on Civil and Political Rights and the International Covenant on Economic, Social, and Cultural Rights. In national law, Article 28I paragraph (4) of the 1945 Constitution states that the protection, advancement, enforcement, and fulfillment of human rights are the responsibility of the state, especially the Government. The Post-Amendment 1945 Constitution includes Chapter XA which discusses human rights. The provisions in that Chapter serve as a form of protection for the constitutional rights of citizens in general, including citizens with disabilities. The goal is that persons with disabilities who are part of Indonesian society have the same position, rights, and obligations as other citizens and for their implementation, it is the obligation of the Government and all elements of society (Mangku, et. al., 2020).

In Chapter XA of the 1945 Constitution, there are 10 articles, namely Article $28 \mathrm{~A}$ to Article $28 \mathrm{~J}$, which cover 26 provisions scattered in the paragraphs in the existing Articles. The entire provision can be divided into two types, namely protection of human rights specifically for citizens and protection of human rights for everyone, which means not only Indonesian citizens. In the two types of groups, there are no other classifications, which means, either in the type of protection for citizens or everyone, groups of persons with disabilities are included in both.

Fulfillment and protection of the rights of persons with disabilities are all actions and/or activities to guarantee and protect the constitutional rights of persons with disabilities by human dignity and to avoid acts of violence and discrimination. The objectives of protecting and fulfilling the rights of persons with disabilities include: increasing the level of welfare, quality, and survival, and independence of persons with disabilities; (a) increase the social and economic resilience of persons with disabilities; (b) increase the capacity, concern, and responsibility of the Provincial Government, the business community and the community in institutional and sustainable protection and fulfillment of the rights of persons with disabilities; and (c) improving the quality of life and livelihoods of persons with disabilities (Yuliartini, 2020).

From the explanation above, the 1945 Constitution has explicitly protected the constitutional rights of persons with disabilities in the context of "everyone" and as part of "citizens". Also, people with disabilities are also allowed to get affirmative action or the right to convenience and special treatment in the context of fulfilling rights. constitutionality. Both concepts must be understood and absorbed in the formation of laws and regulations as well as policies as an implementation of the provisions of the 1945 Constitution. 


\section{CONCLUSION}

Fulfillment and protection of the rights of persons with disabilities are all actions and/or activities to guarantee and protect the constitutional rights of persons with disabilities following human dignity and to avoid acts of violence and discrimination. The objectives of protecting and fulfilling the rights of persons with disabilities include: increasing the level of welfare, quality and survival, and independence of persons with disabilities; (a) increase the social and economic resilience of persons with disabilities; (b) increase the capacity, concern, and responsibility of the Provincial Government, the business community and the community in institutional and sustainable protection and fulfillment of the rights of persons with disabilities; and (c) improve the quality of life and livelihoods of persons with disabilities. The Indonesian government has firmly protected the constitutional rights of persons with disabilities in the context of "everyone" and as part of "citizens". Also, people with disabilities are also allowed to get affirmative action or the right to convenience and special treatment in the context of fulfilling their constitutional rights. Both concepts must be understood and absorbed in the formation of laws and regulations as well as policies as an implementation of the provisions of the 1945 Constitution.

\section{SUGGESTION}

Persons with disabilities have the ability and can contribute to the development of the country like other citizens if they are given the facilities and rights they should get. Cooperation and the attention of the government and society is paying attention to the lives of persons with disabilities and applying the principles of law and regulations properly and fairly are necessary for the realization of the country you aspire to. With the existence of laws and regulations on persons with disabilities as well as laws on human rights, it has become a guarantee for persons with disabilities to be given protection and the fulfillment of their rights without exception.

\section{ACKNOWLEDGEMENTS}

We would like to thank the Faculty of Law, Khairun Ternate University, the Faculty of Law and Social Sciences, Ganesha University of Education, and Dwijendra University, for allowing us to carry out joint research. Hopefully, this research can motivate and encourage other researchers to carry out this joint research.

\section{REFERENCES}

Agus Budi Susilo, 2016, Pembatasan Hak Asasi dan Konsekuens Hukum Bagi Pencari Keadilan Dalam Sistem Peradilan Tata Usaha Negara di Indonesia, Disertasi Program Doktor IImu Hukum, Universitas Gadjah Mada, Yogyakarta.

Arianta, K., Mangku, D. G. S., \& Yuliartini, N. P. R. (2020). Perlindungan Hukum Bagi Kaum Etnis Rohingya Dalam Perspektif Hak Asasi Manusia Internasional. Jurnal Komunitas Yustisia, 3(2), 166-176.

Arifin, R., \& Lestari, L. E. (2019). Penegakan dan Perlindungan Hak Asasi Manusia di Indonesia dalam Konteks Implementasi Sila Kemanusiaan yang Adil dan Beradab. Jurnal Komunikasi Hukum (JKH), 5(2), 12-25. https://doi.org/10.23887/jkh.v5i2.16497

Arstein-Kerslake, A., Gooding, P., Andrews, L., \& McSherry, B. (2017). Human rights and unfitness to plead: the demands of the Convention on the Rights of Persons with Disabilities. Human Rights Law Review, 17(3), 399-419. https://doi.org/10.1093/hrlr/ngx025

Awaliyah Siti et al. (2020), Enforcement of Illegal Fishing Laws that was Done by Foreign Ships in the Indonesian Sea Region, Viewed from International Sea Law, International Journal of Criminology and Sociology, Volume 9. https://doi.org/10.6000/1929-4409.2020.09.137

Dahlan Thaib, 2000, Kedaulatan Rakyat, Negara Hukum dan Hak Asasi Manusia.

Devandas Aguilar, C. (2017). Social protection and persons with disabilities. International social security review, 70(4), 45-65. https://doi.org/10.1111/issr.12152

Duffy, R. M., \& Kelly, B. D. (2017). Rights, laws and tensions: A comparative analysis of the Convention on the Rights of Persons with Disabilities and the WHO Resource Book on Mental Health, Human Rights and Legislation. International journal of law and psychiatry, 54, 26-35. https://doi.org/10.1016/j.ijlp.2017.07.003

Elly Kristiani Purwendah and Dewa Gede Sudika Mangku. (2021). Implementation of Compensation for Oil Pollution by Tanker Ships in the Indonesian Legal System. International Journal of Criminology and Sociology, 2021, 10, 111-119. https://doi.org/10.6000/1929-4409.2021.10.15

Franciscus Adi Prasetyo, "Disabilitas Dan Isu Kesehatan : Antara Evolusi Konsep, Hak Asasi, Kompleksitas Masalah, dan Tantangan", dalam Buletin Jendela Data dan Informasi Kesehatan, Situasi Penyandang Disabilitas, Semester II 2014, Kementerian Kesehatan Republik Indonesia, Jakarta.

George Sabine, 1995, A History of Political Theory,George G.Harrap \& CO.Ltd., London. Itasari, E. R. (2019). Fulfillment Of Education Rights In The Border Areas Of Indonesia And Malaysia. Ganesha Law Review, 1(1), 1-13. https://doi.org/10.23887/glr.v1i1.14

Guide, T. (2010). The convention on the rights of persons with disabilities.

Hamid S. Attamimi, 1992, Teori Perundang-undangan, Pidato pengukuhan Jabatan Guru Besar Tetap Fakultas Hukum UI, 25 April 1992

Harpur, P. (2012). Embracing the new disability rights paradigm: the importance of the Convention on the Rights of Persons with Disabilities. Disability \& Society, 27(1), 1-14. https://doi.org/10.1080/09687599.2012.631794

Hendriks, A. (2007). UN Convention on the Rights of Persons with Disabilities. European Journal of Health Law, 14(3), 273-298. https://doi.org/10.1163/092902707X240620 
Itasari, E. R. (2015). Memaksimalkan Peran Treaty of Amity and Cooperation in Southeast Asia 1976 (TAC) Dalam Penyelesaian Sengketa di ASEAN. Jurnal Komunikasi Hukum (JKH), 1(1). https://doi.org/10.23887/jkh.v1i1.5010

Itasari, E. R. (2020). Border Management Between Indonesia And Malaysia In Increasing The Economy In Both Border Areas. Jurnal Komunikasi Hukum (JKH), 6(1), 219-227. https://doi.org/10.23887/jkh.v6i1.23473

Itasari, E. R. (2020). Equality and Non Discrimination Principles In Providing Rights With Disabilities. Jurnal Komunikasi Hukum (JKH), 6(2), 534-541.

Itasari, E. R. (2020). Perlindungan Hukum Terhadap Penyandang Disabilitas Di Kalimantan Barat. Integralistik, 32(2), 70-82.

Lord, J. E., \& Stein, M. A. (2008). The domestic incorporation of human rights law and the United Nations Convention on the Rights of Persons with Disabilities. Wash. L. Rev., 83, 449.

MacKay, D. (2006). The United Nations Convention on the rights of persons with disabilities. Syracuse J. Int'I L. \& Com., 34, 323.

Mangku Dewa Gede Sudika et al. (2020), Compensation for Oil Pollution Due to Tanker Accidents in the Indonesian Legal System in a Justice Value Perspective, International Journal of Criminology and Sociology, Volume 9. https://doi.org/10.6000/1929-4409.2020.09.63

Mangku, D. G. S. (2012). Suatu Kajian Umum tentang Penyelesaian Sengketa Internasional Termasuk di Dalam Tubuh ASEAN. Perspektif, 17(3), 150-161. https://doi.org/10.30742/perspektif.v17i3.104

Mangku, D. G. S. (2017). The Efforts of Republica Democratica de Timor-Leste (Timor Leste) to be a member of Association of Southeast Asian Nations (ASEAN) and take an active role in maintaining and creating the stability of security in Southeast Asia. Southeast Asia Journal of Contemporary Business, Economics and Law, 13(4), 18-24.

Mangku, D. G. S. (2020). Perlindungan Hukum Terhadap Anak-Anak Disabilitas Terkait Hak Pendidikan di Kabupaten Buleleng. Jurnal Magister Hukum Udayana (Udayana Master Law Journal), 9(2), 353-365. https://doi.org/10.24843/JMHU.2020.v09.i02.p11

Mangku, D. G. S., \& Itasari, E. R. (2015). Travel Warning in International Law Perspective. International Journal of Business, Economics and Law, 6(4), 33-35.

Mangku, D. G. S., \& Yuliartini, N. P. R. (2019). Indonesia's Role In Enabling ASEAN 2025 Masterplants To Promote And Protect Disability Rights In Asean. South East Asia Journal of Contemporary Business, Economics and Law, Vol. 18, Issue 4 (April).

Mangku, D.G.S., Purwendah, E.K., Itasari, E.R., Nurhayati, B.R. (2020). Compensation for Oil Pollution Due to Tanker Accidents in the Indonesian Legal System in a Justice Value Perspective. International Journal of Criminology and Sociology, 2020, 9, pp. 662-669. https://doi.org/10.6000/1929-4409.2020.09.63

Mannan, H., MacLachlan, M., McVeigh, J., \& EquitAble Consortium. (2012). Core concepts of human rights and inclusion of vulnerable groups in the United Nations Convention on the rights of persons with disabilities. Alter, 6(3), 159-177. https://doi.org/10.1016/j.alter.2012.05.005

Maria SW. Sumardjono, 1989, Pedoman Pembuatan Usulan Penelitian, tanpa penerbit, Yogyakarta.

Maria SW. Sumardjono, 2014, Metodologi Penelitian IImu Hukum, Bahan Kuliah, Universitas Gadjah Mada, Yogyakarta.

Márton, S. M., Polk, G., \& Fiala, D. R. C. (2013). Convention on the Rights of Persons with Disabilities.

Mégret, F. (2008). The disabilities convention: Human rights of persons with disabilities or disability rights?. Human Rights Quarterly, 494-516.

https://doi.org/10.1353/hrq.0.0000
Minkowitz, T. (2010). Abolishing mental health laws to comply with the Convention on the Rights of Persons with Disabilities. Rethinking rights-based mental health laws, 151177.

Mukti Fajar ND, dan Yulianto Achmad, 2010, Dulaisme Penelitian Hukum Normatif dan Empiris, Pustaka Pelajar, Yogyakarta.

Muslan Abdurrahman, 2009, Sosiologi dan Metode Penelitian Hukum, UMM Press, Malang, 2009.

Ni'matul Huda, 2005, Negara Hukum, Demokrasi dan Judicial Riview, UII Press, Yogyakarta.

Ortoleva, S. (2010). Inaccessible justice: Human rights, persons with disabilities and the legal system. ILSA J. Int'I \& Comp. L., 17, 281.

Pengantar Redaksi Majalah Hukum dan HAM Nomor.24 May - Juni 2007, Biro Humas dan HLN Departemen Hukum dan HAM, Jakarta.

Philipus M. Hadjon, 1996, Kedaulatan Rakyat,Negara Hukum dan Hak-hak Asasi Manusia, Kumpulan Tulisan dalam rangka 70 tahun Sri Soemantri Martosoewignjo, Media Pratama, Jakarta.

Purwendah Elly Kristianti and Mangku Dewa Gede Sudika (2021), Implementation of Compensation for Oil Pollution by Tanker Ships in the Indonesian Legal System, International Journal of Criminology and Sociology, Volume 9. https://doi.org/10.6000/1929-4409.2020.09.63

Purwendah, E. K., Mangku, D. G. S., \& Periani, A. (2019, May). Dispute Settlements of Oil Spills in the Sea Towards Sea Environment Pollution. In First International Conference on Progressive Civil Society (ICONPROCS 2019). Atlantis Press. https://doi.org/10.2991/iconprocs-19.2019.51

Satjipto Raharjo, 2009, Hak Asasi Manusia Dalam Masyarakatnya dalam Muladi (ed), 2009, Hak Asasi Manusia Hakekat, Konsep dan Implikasinya dalam Perspektif Hukum dan Masyarakat, PT Reflika Aditama, Bandung.

Siti Nurdjanah, 2017, Kedudukan Hakim Sebagai Pejabat Negara Dalam Rangka Mewujudkan Independensi Yudisial, Disertasi Program Doktor IImu Hukum Fakultas Hukum, Universitas Gadjah Mada, Yogyakarta.

Soerjono Soekanto, dan Sri Mamudji, 2006, Penelitian Hukum Normatif; Suatu Tinjauan Singkat, PT. Rajagrafindo Persada, Jakarta. Soetandyo Wignjosoebroto, 2013, Hukum, Konsep, dan Metode, Setara Press, Malang.

Suastika I Nengah et al. (2020), The Multi-Etnik Community Integration Model in Bali: Pholosphical Base and Proto Multiculturalism in Balinese Society, International Journal of Criminology and Sociology, Volume 9. https://doi.org/10.6000/1929-4409.2020.09.142

Sulistyowati Irianto dan Shidarta (editor), 2011, Metode Penelitian Hukum; Konstelasi dan Refleksi, Yayasan Pustaka Obor Indonesia, Jakarta.

Szmukler, G., Daw, R., \& Callard, F. (2014). Mental health law and the UN Convention on the rights of persons with disabilities. International journal of law and psychiatry, 37(3), pp. 245-252.

https://doi.org/10.1016/j.ijlp.2013.11.024

Undang Undang Nomor 4 Tahun 1997 Tentang Penyandang Cacat (Lembaran Negara Tahun 1997 Nomor 9, Tambahan Lembaran Negara Nomor 3670)

Undang Undang Nomor 8 Tahun 2016 Tentang Penyandang Disabilitas (Lembaran Negara. Nomor 69. Tambahan Lembaran Negara. Nomor 5870)

Undang-Undang Nomor 19 Tahun 2011 tentang Pengesahan Convention On The Right Of Persons With Disabilities (Lembaran Negara Republik Indonesia Tahun 2011 Nomor 107, Tambahan Lembaran Negara Republik Indonesia Nomor 5251). 
Undang-Undang RI Nomor 39 Tahun 1999 tentang Hak Asasi Manusia

Yuliartini Ni Putu and Mangku Dewa Gede Sudika (2020), Legal Protection for Women Victims of Trafficking in Indonesia in an International Human Rights Perspective, International Journal of Criminology and Sociology, Volume 9.

https://doi.org/10.6000/1929-4409.2020.09.160

Received on 09-01-2021

Accepted on 08-02-2021

Published on 22-02-2021

DOI: https://doi.org/10.6000/1929-4409.2021.10.62

(C) 2021 Malik et al.; Licensee Lifescience Global.

This is an open access article licensed under the terms of the Creative Commons Attribution Non-Commercial License (http://creativecommons.org/licenses/by-nc/3.0/) which permits unrestricted, non-commercial use, distribution and reproduction in any medium, provided the work is properly cited. 